\title{
Consensus
}

Volume 29

Issue 1 Hospitality - The Healing of the World

Article 21

$5-25-2003$

\section{Witnessing and Testifying: Black Women, Religion, and Civil Rights}

Oscar Cole-Arnal

Follow this and additional works at: http://scholars.wlu.ca/consensus

\section{Recommended Citation}

Cole-Arnal, Oscar (2003) "Witnessing and Testifying: Black Women, Religion, and Civil Rights," Consensus: Vol. 29 : Iss. 1 , Article 21.

Available at: http://scholars.wlu.ca/consensus/vol29/iss1/21

This Book Reviews is brought to you for free and open access by Scholars Commons @ Laurier. It has been accepted for inclusion in Consensus by an authorized editor of Scholars Commons @ Laurier. For more information, please contact scholarscommons@wlu.ca. 


\section{Witnessing \& Testifying:}

\section{Black Women, Religion, and Civil Rights}

Rosetta E. Ross

Minneapolis: Fortress Press, 2003

294 pages, $\$ 24.43$ Softcover

Witnessing \& Testifying gives us a series of vignettes highlighting the contribution of Afro-American women to the on-going struggle for civil rights and human dignity. In these cameos we encounter a rich blend of black womanist theology and liberation from the nineteenth century to the present with special emphasis on the impact of the Christian faith on their activism. Ms. Ross introduces us to the everexpanding group of black womanist theologians who have begun to recover the repressed history of Afro-American women. From the original slave culture they have blended survival and "racial uplift" strategies to make their mark on both their own culture and the wider oppressive society they encountered in their life journeys. After vignettes of the insight of these sister theologians, the author turns to the powerful twin themes of "witnessing and testifying" followed by a journey of personal cameos through the years of history.

We read of the great abolitionist, suffragist and revival preacher Sojourner Truth and Nannie Helen Burroughs' work for women within her Baptist church as well as her organizing black women in wider community causes. Between the end of slavery and the modern civil rights movement, Witnessing \& Testifying brings to our attention two black female activists, Ella Baker and Septima Poinsette Clark. Standing out in the great activism of the 1950s and 1960s is the almost mythical figure of Fannie Lou Hamer. Driven by her early sharecropper reality and the inspiration of her hard-driven mother, Hamer vowed to face off against the injustice meted out against AfroAmericans. Joining the SNCC voter registration drive in the early 1960s she discovered the courage that compelled her to live out her vision. Throughout the harassment, beatings and jail cells, Ms. Hamer never lost her sense of the vital importance of the black churches' visions of freedom. "I tell young people don't write off the Church and don't write off God," she testified. "If something is wrong with the Church, stand up and change it and make it relevant to the community." 
Witnessing \& Testifying pays tribute also to the work of community activist Clara Muhammad, the wife of and co-founder with Elijah Muhammad (Poole) of the movement known popularly as the "Black Muslims." Special tribute is paid to her work in grassroots education. After vignettes about black women students (chiefly in SNCC) in the movements of the 1960s, the collection closes with analyses of the religious underpinnings of "witnessing and testifying" found among those black women who remain models of reflection and practice for Afro-American women then and now. All told, Rosetta Ross' Witnessing \& Testifying represents a fine jewel in the necklace of black "womanist" theology, serving the wider community of faith both intellectually and as a profound source of inspiration.

Oscar Cole-Arnal

Waterloo Lutheran Seminary

Waterloo, Ontario

\section{Moving from Shame to Self-Worth: Preaching and Pastoral Care}

Edward Wimberly

Nashville: Abingdon Press, 1999

131 pages, \$21.24 Softcover

Edward Wimberly tackles the issue of shame in pastoral ministry. Writing from an Afro-American context, as well as an educator of pastoral counsellors in an academic setting, he believes that the challenge is to foster self-worth in those who live a shame-based life. Wimberly's principal method is to draw on the way that Jesus dealt with shame as outlined in the Biblical record and apply this to contemporary experience. The book is divided into how Jesus dealt with shame (1) in his own life, (2) in the lives of others, and (3) in the parables. He describes how Jesus transformed these shame-based moments into self-worth. Wimberly uses many examples from his own preaching and pastoral care to illustrate how this can be mimicked today. 